DOI https://doi.org/10.18551/rjoas.2018-05.32

\title{
POSTHARVEST DEVELOPMENT STRATEGIES OF CORN AGRIBUSINESS IN GROBOGAN DISTRICT
}

\author{
Zuhri Nur Muttaqien \\ Master Program of Agribusiness, Faculty of Animal and Agricultural Sciences, \\ Diponegoro University, Indonesia \\ Prasetiyono Bambang Waluyo Hadi Eko, Yunianto Vitus Dwi \\ Faculty of Animal and Agricultural Sciences, Diponegoro University, Indonesia \\ *E-mail: nurmuttaqienzuhri@gmail.com \\ ORCID: 0000-0001-9837-1579
}

\begin{abstract}
The declining quality of corn, on the acceptance of raw materials in an industry caused by postharvest process at the level of farmers in Grobogan District that is still not appropriate, has resulted in the low price of the corn. The aim of this research was to know and evaluate the implementation of Good Handling Practices (GHP) in corn postharvest in Grobogan District and to determine the priority strategy in developing corn postharvest activities in Grobogan District. This research used the data sources obtained from interviews and questionnaires from the corn farmers and the related stakeholders. Furthermore, the data were analyzed descriptively using GHP checklist analysis method, SWOT analysis and AHP analysis. The findings showed that the application of GHP for farmers at the level of storage, facilities and cleanliness and recording was still not appropriate. From the SWOT analysis, the matrix position of postharvest activities was in quadrant I (S-O) which supported the development of competitive corn postharvest activities. The obtained AHP priority strategy was coaching and mentoring in corn postharvest activities (weight 0.412 ). In the priority alternatives from the 9 aspects, the most important aspect in the priorities of corn postharvest development was the improvement of postharvest modern technology (0.273). By having the improvement of technology, postharvest activities were expected to run effectively and efficiently so that the corn commodities will be competitive.
\end{abstract}

\section{KEY WORDS}

Corn, postharvest, quality, competitive, price.

Corn is one of the main food commodities that play a very important role in supporting the availability of food. Corn production in Indonesia continues to increase over time as market demand continues to increase (Revina, 2008). Corn is one of agricultural commodities which is also the main component of raw materials in industry especially in the manufacture of feed which is widely used in preparing feed rations.

Grobogan District is one of the largest corn-producing areas in Central Java Province and is a leading agricultural commodity other than rice and soybeans. Every year, corn production in Grobogan District is increasing. By 2015, corn production reached 700,941 tons (Central Bureau of Statistics of Grobogan District, 2016). However, the high quantity of corn production is not balanced with the quality of shelled corn. The declining quality of corn is due to the poor handling of postharvest activities at the farmer level and most of the corn harvest is sent to the feed industry.

The national feed industry, in 2015 , grew by $12 \%$ which was marked by an increase in feed consumption by 16 million tons compared to 2014 by 14.9 million tons. In particular, the contribution of corn raw materials to feed industry in 2015 will increase from 7.5 million tons in 2014 by 7 million tons (Department of Communications and Informatics, 2016). It is estimated in the 2016 period, the consumption of animal feed reached 16.4 million tons (Joint 
Livestock Feed Company, 2016). Grobogan District is the main supplier of corn raw material to the feed industry in Central Java.

The acceptance of raw materials in the feed industry always implements high quality standards. Thus, many corns from the farmers are purchased at low prices because the quality of the corn is not in accordance with the quality standard. Quality assurance is vital to the food and feed industry. Quality assurance can be generated by the application of Good Agricultural Practices (GAP) and Good Handling Practices (GHP) to improve the quality and guarantee the products (Hermansyah et al., 2013); such as through commodity quality management system which is in accordance to market demand.

As a major component in feed industry, the quality of corn will greatly affect the overall feed quality which will ultimately affect the productivity of livestock consuming the feed; according to research conducted by Novitasari (2016). According to Kereth et al. (2013), there was a quite high evaluation of losses from Good Handling Practices (GHP) in postharvest. The causes are human, technology and infrastructure provision factors. Therefore, efforts are needed to reduce postharvest damage or losses and improve the quality of crops. Meanwhile, based on a research conducted by Khalil and Anwar (2016), the quality of corn is not considered to be good if the drying process and postharvest handling are not carried out properly. At the time of harvesting, corn has fairly high water content, about $30-40 \%$, in which the corn will be easily damaged corn if it is not handled appropriately. Based on the opinion from Fitriati et al. (2015), priority strategy for corn postharvest activities is the quality of conformity of Indonesian National Standard (SNI), criteria of facility price and fixed cost, technological criteria, institutional human resource quality and location of varietal difference.

The aim of this research was to know and evaluate the implementation of Good Handling Practices (GHP) in corn postharvest in Grobogan District and to determine the priority strategy in developing corn postharvest activities in Grobogan District.

\section{METHODS OF RESEARCH}

The research was conducted in Pulokulon, Toroh and Geyer Sub-Districts in December 2017 - February 2018. The selection of the research setting was conducted purposively with the consideration that the areas were the highest corn production center in Grobogan District (Central Bureau of Statistics of Grobogan District, 2016).

From each selected Sub-District, it purposively determined 2 villages which had the largest agricultural land and corn farming; respectively from Pulokulon Sub-District were Pojok Village and Mlowo Village, Toroh Sub-District were Tunggak Village and Boloh Village, and Geyer Sub-District were Rambat Village and Bangsri Village. Calculation of Slovin formula yielded the total of 90 respondents as sample using simple random sampling system. The formulation of internal and external factors was performed using Forum Group Discussion (FGD) by 12 key persons consisting of government, academicians, farmers and collectors (Sugiyono, 2001).

Primary data were obtained through direct observation, in-depth interviews and filling out an evaluation questionnaire about postharvest handling by the respondents guided by the researcher. In addition, secondary data were obtained from previous research, books, journals, data from the Agricultural Service of Grobogan District and Central Bureau of Statistics of Grobogan District.

Corn postharvest evaluation was conducted using a structured check sheet questionnaire that had been modified according to Good Handling Practices (GHP) guidelines by employing the corn farmers (Pennstate, 2012). The determination of alternative strategies was done by using SWOT analysis to identify the internal (strengths and weaknesses) and external (opportunities and threats) factors in postharvest activities and formulate future corn postharvest development strategies (Rangkuti, 2006).

The determination of priority strategy of corn postharvest development in decision making was performed by using hierarchy framework from Analysis Hierarchy Process (AHP) with comparison partner in decision process which was performed by the key person. 
Furthermore, the data were processed using Expert Choice software (Firdaus and Farid, 2008).

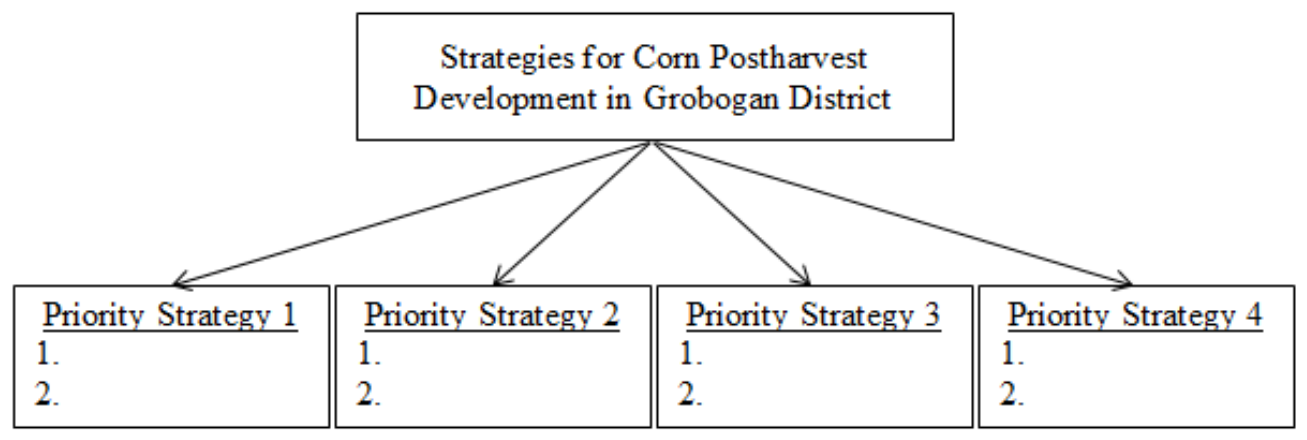

Figure 1 - Analysis Hierarchy Process (AHP) Framework

\section{RESULTS AND DISCUSSION}

Overview on the Respondents of Corn Farmers in Grobogan District. The average age of the respondents of corn farmers in Grobogan District was 50 years old. It meant that their age was old enough to conduct farming so that they might experience a decrease in the performance and it would affect the productivity of corn farming. It was in accordance with the opinion of Mohamad, Nur and Abd (2016) that the productive age of a farmer ranges from 25-35 years. Productive age will affect the productivity of farming product.

The educational background of corn farmers in Grobogan District was high school graduates on average. The high level of education will usually affect the absorption of information and application of technology and innovation in every corn postharvest farming activity. From the findings of a research conducted by Mohamad et al. (2016), the level of education is one of the supporting factors in farming activities, because it is closely related to someone's ability in their way of thinking. Thus, it becomes the basis in adopting a technological innovation of farming in corn agribusiness development.

Average land area of corn farmers in Grobogan District was 0.86 ha. Farmers' land was considered to be wide enough and the greater the agricultural land, the higher the yield of corn production. It was supported by the opinion of Setiawan et al. (2014) that the more widely used agricultural land will affect the commodity as well. Corn farmers in Grobogan District had an average farming experience for 23 years. It showed that the corn farmers had a long experience. The longer the experience they have, the more stable the farming. This opinion was also supported by the findings of Aji et al. (2014) research that farmers with sufficient experience tend to overcome the problems that arise in the implementation of the business and able to use efficient solutions to the problem so as to generate maximum business profits.

Table 3 - Overview on the Respondents of Corn Farmers in Grobogan District

\begin{tabular}{cc}
\hline Indicators & Average \\
\hline Age (year) & 50 \\
Educational background & High School \\
Land area (ha) & 0.86 \\
Farming experience (year) & 23 \\
\hline
\end{tabular}

Source: The processed primary data (2018).

Evaluation of Good Handling Practices (GHP) Implementation of Corn Postharvest. Good Handling Practices (GHP) is a postharvest method related to the application of technology and utilization of facilities and infrastructure (Lukman, 2013). Implementation of good and proper cultivation techniques and appropriate GAP (Good Agriculture Practices) is not enough to provide quality assurance without paying attention to postharvest handling of 
good products. Application of GHP is one of the quality control processes so that a commodity has guaranteed quality and can be accepted by market and competitive.

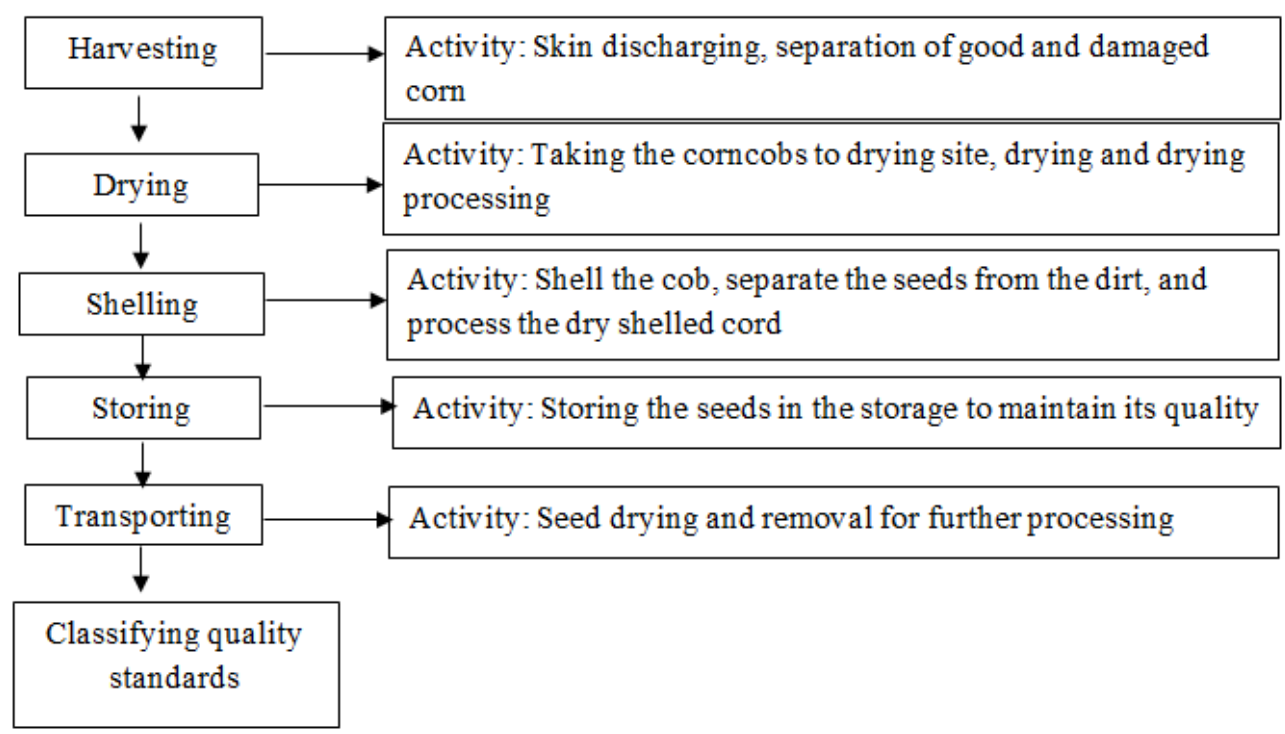

Figure 2 - Flow Chart of Corn Postharvest Process

Postharvest stages at the corn farmer level (Figure 2) consist of 6 stages consisting of harvesting, drying, shelling, storing, transporting and classifying quality standards. The evaluation of Good Handling Practices (GHP) implementation in postharvest activities in Grobogan District showed overall that it had not been well implemented by the corn farmers.

Table 4 - Evaluation of Good Handling Practices (GHP) on Corn Postharvest Activity

\begin{tabular}{|c|c|}
\hline Postharvest Components & Percentage (\%) \\
\hline \multicolumn{2}{|l|}{ Harvest } \\
\hline - $\quad$ Corncob with husks & 75 \\
\hline - $\quad$ Corncob with no husks & 0 \\
\hline - $\quad$ Others & 25 \\
\hline \multicolumn{2}{|l|}{ Drying Method } \\
\hline - $\quad$ Being dried with no husks using plastic pads & 89.75 \\
\hline - Being hanged in the kitchen or other place & 9.27 \\
\hline - Other & 0.98 \\
\hline \multicolumn{2}{|l|}{ Shelling Method } \\
\hline - Using hands & 3.25 \\
\hline - Using shaver & 20.45 \\
\hline - Using machine & 76.30 \\
\hline \multicolumn{2}{|l|}{ Drying after the Shelling Process } \\
\hline - $\quad$ Being dried in the sun & 74.80 \\
\hline - $\quad$ Not being dried in the sun & 25.2 \\
\hline \multicolumn{2}{|l|}{ Duration of Storing } \\
\hline - $\quad<7$ days & 4.55 \\
\hline - $7-14$ days & 0.00 \\
\hline - $\quad 14$ days - 1 month & 13.64 \\
\hline - 3 months & 27.27 \\
\hline - $\quad>3$ months & 54.55 \\
\hline \multicolumn{2}{|l|}{ Storing Method } \\
\hline - In the form of shelled corn in a sack & 43.68 \\
\hline - In the form of cornstarch in a plastic bag & 6.12 \\
\hline - In the form of corncob & 20.14 \\
\hline - Others & 30.06 \\
\hline \multicolumn{2}{|l|}{ Sanitation } \\
\hline - $\quad$ Sanitation & 28.72 \\
\hline - $\quad$ Facilities and infrastructure & 42.80 \\
\hline \multicolumn{2}{|l|}{ Recording } \\
\hline - $\quad$ Recording the farming activities & 12.43 \\
\hline - $\quad$ No recording on the farming activities & 87.57 \\
\hline
\end{tabular}

Source: The processed primary data (2018). 
Evaluation of postharvest activities that had not been properly applied is a drying process. Stages of drying are an important process in producing high quality corn because good quality corn has low moisture content. The lower the water content produced then the selling price of the corn will be more competitive. The selling price of corn in Grobogan District at the farmer level in February 2018 was IDR 3500/kg. In accordance with the opinion of Miskiyah and Widaningrum (2010), the average level of moisture content at the farm level was still relatively high; which was about $19 \%$. In fact, the average moisture content for imported corn was $14 \%$. Therefore, many feed industries used imported corn. Meanwhile, based on the opinion of Falatehan and Wibowo (2008), the drying process was not good because the farmers were still using natural dryer that was from sunlight and did not have modern corn drying facilities.

Other postharvest processes that had not been good were the means and facilities for corn storage. The corn storage was still simple and was not also supported with good hygiene and sanitation so that affect the quality of the corn. If the storage warehouse is not handled properly, it will result in fungus and aflatoxin in corn. High levels of aflatoxin will cause poisoning and death when corn is consumed by livestock or humans. In accordance with research conducted by Kusumaningrum et al. (2010), in addition to unsuitable temperature and humidity factors, the absence of hygiene and sanitation of the storage room will potentially cause aflatoxin. The high level of aflatoxin results in the corn quality. It was supported also by the opinion of Yusrini (2010) that the limit of aflatoxin tolerance in corn was $50 \mathrm{ppb}$ and for feed was $100 \mathrm{ppb}$.

The level of knowledge of corn farmers on average was low-educated, so in conducting farming process from cultivation to postharvest process had never recorded the farming. As a result, farmers did not have accurate data related to corn production and only relied on farming experience. Recording has a function that when there are irregularities in corn farming, it will be able to trace the source of the problem and able to make better farming planning in the future. According to research conducted by Leatemia and Sari (2012), attitudes and skills of farmers about recording the farming was still low. In fact, with good and appropriate farming record, farmers will be able to manage farming finances well so that future farming planning becomes more organized. Thus, in doing their farming, besides acting as themselves, they also play a role as manager.

SWOT Analysis of Strategy of Corn Postharvest Development Agribusiness:

Internal factors: Strengths and Weaknesses. Based on the obtained data and information, several factors that become the strength in corn postharvest development farming are as follows:

1. High motivation of the farmers. High desire of corn farmers in Grobogan District to be able to conduct postharvest activities properly and correctly will have an impact on the results of good quality corn.

2. Facilities and infrastructure. The condition of the facility is sufficient to support the corn postharvest activities appropriately.

3. Farming experience. Most of the corn farmers in Grobogan District have been doing corn farming for a long time, so they have experience in corn postharvest activities which is expected to do it well and correctly.

4. Government cooperation in postharvest activities. The government, in this case Grobogan District Agricultural Office, through counseling, always provides education and assistance in corn postharvest activities.

5. Availability of human resources. Part of Grobogan District is agricultural land so that most of Grobogan District people is farmers.

6. Market access. Strategic location to big cities makes agricultural commodities in Grobogan District have access to promising market network.

7. Amount of corn income. Corn is a superior commodity besides rice and soybean in Grobogan District which makes the commodity farming quite potential.

In addition, the weakness factors in corn postharvest development farming in Grobogan District are: 
1. Postharvest handling sanitation. The facilities and infrastructure are good but not supported by the hygiene system or have poor sanitation. That will lead to poor corn quality.

2. The technology is still traditional. Government support, in this case Agricultural Office Grobogan District, is only in the assistance and gives no assistance or appropriate technology that can be used by the farmers. Thus, they still use traditional tools.

3. Capital capability. Farmers often have difficulty in terms of farming capital so that farmers make a lot of debt to run their farms with high interest.

4. Recording or bookkeeping in postharvest activities. Corn postharvest activities in Grobogan District have not been able to run well since most farmers have not realized the importance of recording in the farming activities.

5. Concern in postharvest. The concern of farmers in corn postharvest is still very low so that the quality is not in accordance with market demand.

Internal factors that illustrate the strengths and weaknesses in the corn postharvest development strategy in Grobogan District are summarized into the factor matrix of internal strategy of IFAS (Internal Factor Analysis Summary).

Table 5 - IFAS (Internal Factor Analysis Summary) Matrix

\begin{tabular}{llll}
\hline Internal Strategy Factors & Weight & Rating & Value \\
\hline Strengths & & & \\
1. High motivation of the farmers & 0.08 & 3.47 & 0.27 \\
2. Good facilities and infrastructure & 0.07 & 3.20 & 0.22 \\
3. Farming experience & 0.09 & 3.13 & 0.28 \\
4. Cooperation with government in postharvest process & 0.09 & 3.53 & 0.32 \\
5. Availability of human resources & 0.09 & 3.47 & 0.31 \\
6. Market access & 0.09 & 3.47 & 0.31 \\
7. Amount of income from corn farming & 0.09 & 3.47 & 0.31 \\
\hline Total & 0.60 & & 2.03 \\
\hline Weaknesses & & & \\
8. Sanitation in postharvest handling & 0.08 & 2.80 & 0.22 \\
9. Traditional technology & 0.07 & 2.87 & 0.20 \\
10. Capital capability & 0.07 & 3.13 & 0.22 \\
11. Postharvest recording & 0.06 & 3.13 & 0.19 \\
12. Concern in postharvest process & 0.06 & 2.81 & 0.17 \\
\hline Total & 0.34 & & 0.99 \\
\hline
\end{tabular}

Source: The processed primary data (2018).

The results of IFAS matrix assessment (Table 5) show that the total score of power factor is 2.03 and the score on the weakness is 0.99 . It shows that corn postharvest development strategy in Grobogan District had greater strength compared to its weakness with the difference of 1.04 .

External Factors: Opportunity and Threat. Based on the obtained data and information, several factors that become opportunities in corn postharvest development farming are as follows:

1. Postharvest technology. The government plan, in this case the Grobogan District Agricultural Office, pays great attention to the transition of traditional technology to modern technology which is expected to be an excellent opportunity to help farmers in postharvest activities so that they can be more effective and efficient in working.

2. Improving the corn quality. By having government's program plan to support corn postharvest development at the farmer level supported by modern technology, it is expected that farmers can produce quality corn so as to meet the quality standards of market demand.

3. The define market. Grobogan District which is the center of corn commodity is a potential market to produce corn with high production and good quality too, so that the corn produced by the farmers will be bought with high price by feed industry. 
4. Farmer's increasing income. Postharvest development that has been running well is expected to produce quality and competitive corn in market price. So that it will indirectly improves the economic income of farmers in Grobogan District.

5. The level of postharvest knowledge is getting better. With the assistance program plan in postharvest activities, it is expected that farmers' motivation will grow high in improving corn postharvest process so that it will provide better knowledge to the farmers about how important the application of GHP to corn postharvest process.

6. Government support. Corn is a superior commodity besides rice and soybean in Grobogan District. Government role and support are expected in their farming.

7. The improvement of facilities and infrastructure. With a good level of knowledge, ongoing facilitation and transfer of modern technology, it is expected that improvements will be made in terms of facilities and infrastructure in corn farming.

In addition, the threat factors in corn postharvest development farming in Grobogan District are as follow:

1. Fluctuation of corn prices. Corn postharvest handling that has not run appropriately will affect the price of corn at the market level. It is because the quality of corn that has been produced is not in accordance with the standards that have been set so that the selling price of corn will be below the market standard price.

2. The entry of imported corn commodities. Demand for corn raw material for the feed industry cannot be balanced with the supply of local corn raw materials, especially from Grobogan District. Therefore, the feed industry decides to import the corn for the supply of raw materials.

3. Lack of assistance in corn postharvest process. Assistance from the government, to farmers in the application of corn postharvest GHP, is still lacking due to limited human resources. Thus, the role of government in providing mentoring cannot be maximized.

4. Quality is not up to standard. Corn postharvest activities in Grobogan District are still not good so it affects the quality of shelled corn which is difficult for it to be accepted by the market.

5. Competition of corn farming. Corn is a lucrative farming commodity. So, there will be competition between commodities of the same type with the possibility that they will rely on different quality of the corn.

Environmental factors that reflect opportunities and threats are presented in the factor matrix of the external strategy of EFAS (External Factor Analysis Summary).

Table 6 - EFAS (External Factor Analysis Summary) Matrix

\begin{tabular}{rlll}
\hline External Strategy Factors & Weight & Rating & Value \\
\hline Opportunities & & & \\
1. Postharvest technology & 0.08 & 3.60 & 0.30 \\
2. Improving the corn quality & 0.09 & 3.41 & 0.31 \\
3. The define market & 0.09 & 3.67 & 0.33 \\
4. Farmer's increasing income & 0.09 & 3.47 & 0.31 \\
5. The level of postharvest knowledge is getting better & 0.08 & 2.8 & 0.22 \\
6. Government support & 0.09 & 2.87 & 0.26 \\
7. The improvement of facilities and infrastructure & 0.07 & 3.07 & 0.21 \\
\hline Total & 0.59 & & 1.95 \\
\hline Threats & & & 0.26 \\
8. Fluctuation of corn prices & 0.08 & 3.40 & 0.20 \\
9. The entry of imported corn commodities & 0.06 & 3.33 & 0.22 \\
10. Lack of assistance in corn postharvest process & 0.06 & 3.61 & 0.14 \\
11. Quality is not up to standard & 0.06 & 2.4 & 0.17 \\
\hline 12. Competition of corn farming & 0.06 & 2.87 & \\
\hline
\end{tabular}

Source: The processed primary data (2018).

Based on the identification of external factors (Table 6), the opportunity score is 1.95 and the threat score is 0.99 . Thus, it shows that the opportunity has greater score than the 
threat by a margin of 0.96 . after obtaining the internal factor and external factor scores, the next is determining SWOT matrix. In the SWOT matrix, the $X$ axis is the difference between strength and weakness, while the $Y$ axis is the difference between opportunity and threat. Difference in scores of strengths, weaknesses, opportunities and threats resulted in a coordinate score of $1.04 ; 0.96$.

The strategic positions of the four alternatives are: in the first quadrant the strategy choice is the aggressive strategy or SO strategy (strengths-opportunities), in the second quadrant of strategy choice is the diversification strategy or ST strategy (strengths-threats), in the third quadrant the strategy choice is improvement strategy or strategy WO (weaknesses-opportunities) and in the fourth quadrant the strategy choice is defense and dis-survival strategy or WT strategy (weakness-threats). The strategy of corn postharvest process in Grobogan District is produced in the first quadrant (Figure 3). It means that corn postharvest development strategy supports aggressive growth by exploiting the existing opportunities (Rangkuti, 2006).

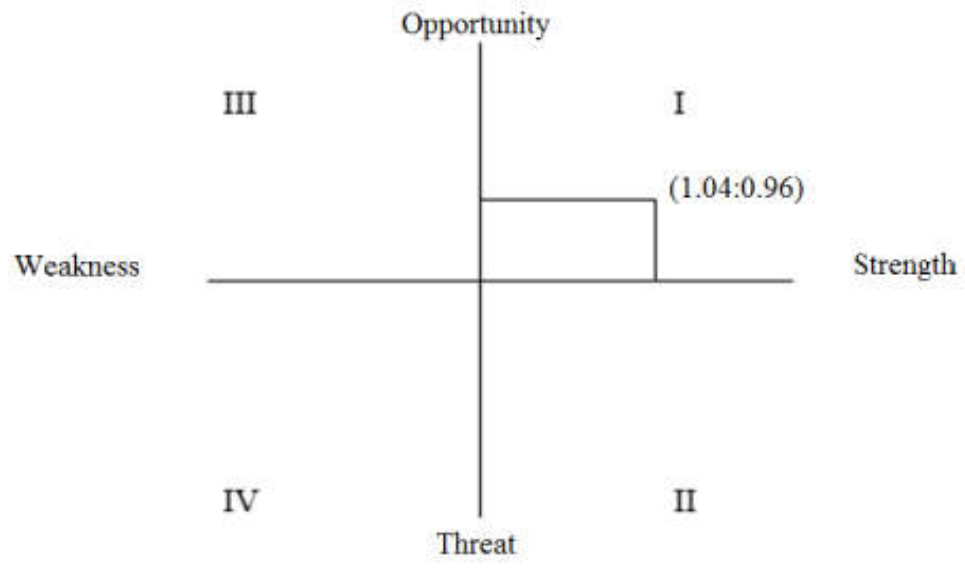

Figure 3 - SWOT Matrix of Corn Postharvest in Grobogan District

Table 7 - Analysis Formulation of SWOT Matrix

\begin{tabular}{|c|c|}
\hline $\begin{array}{r}\text { IFAS } \\
\text { (Internal Factor } \\
\text { Analysis Strategy) }\end{array}$ & $\begin{array}{l}\text { Opportunity } \\
\text { 1. Postharvest technology } \\
\text { 2. Improving the corn quality } \\
\text { 3. The define market } \\
\text { 4. Farmer's increasing income } \\
\text { 5. The level of postharvest knowledge is getting } \\
\text { 6. Gover } \\
\text { 7. The impront support } \\
\end{array}$ \\
\hline $\begin{array}{l}\text { Strengths } \\
\text { 1. High motivation of the farmers } \\
\text { 2. Good facilities and infrastructure } \\
\text { 3. Farming experience } \\
\text { 4. Cooperation with government in postharvest } \\
\text { 5. The availability of human resources } \\
\text { 6. Market access } \\
\text { 7. Amount of income from corn farming }\end{array}$ & $\begin{array}{l}\text { S-O Strategy } \\
\text { 1. The improvement of postharvest technology } \\
\text { 2. The application of commodity quality standards } \\
\text { 3. The reinforcement of market development } \\
\text { 4. Sustainable consultation for the farmers } \\
\text { 5. The development of postharvest supporting } \\
\text { facilities } \\
\text { 6. The improvement of commodity quality } \\
\text { 7. The improvement of commodity capacity and } \\
\text { quantity }\end{array}$ \\
\hline
\end{tabular}

Source: The processed primary data (2018).

S-O Strategy (Table 7) includes: The improvement of postharvest technology, the application of commodity quality standards, the reinforcement of market development, sustainable consultation for the farmers, the development of postharvest supporting facilities, the improvement of commodity quality, and the improvement of commodity capacity and quantity. According to research conducted by Maramba (2018), technological improvement is 
very important in farming; the better the technology used the better quality standard. Indirectly, commodities will be competitive at the marketing level. As Pratama and Sahaya (2014) adds that farming assistance to change the mindset is very important. Thus, there will be awareness from farmers to improve the quality of commodity products. Meanwhile, Pamungkas et al. (2015) argue that the supporting facilities in farming are very important in producing quality commodities. Unsupported facilities will cause damage to the commodity itself, thereby lowering the selling price of commodities.

Determination of Priority Strategy in Corn Postharvest Development. The determination of priority strategy in corn postharvest development is by conducting FGD (Focus Group Discussion) which was carried out by 12 key persons consisting of 3 academicians, 3 officials of agriculture institution, 1 businessman, 3 from corn farmers, 1 from agricultural counselor and 1 person from local village apparatus. Determination of criteria and strategic alternatives undertaken to make priority policy in the development of postharvest activities of corn commodities in Grobogan District is by considering the results of SWOT analysis.

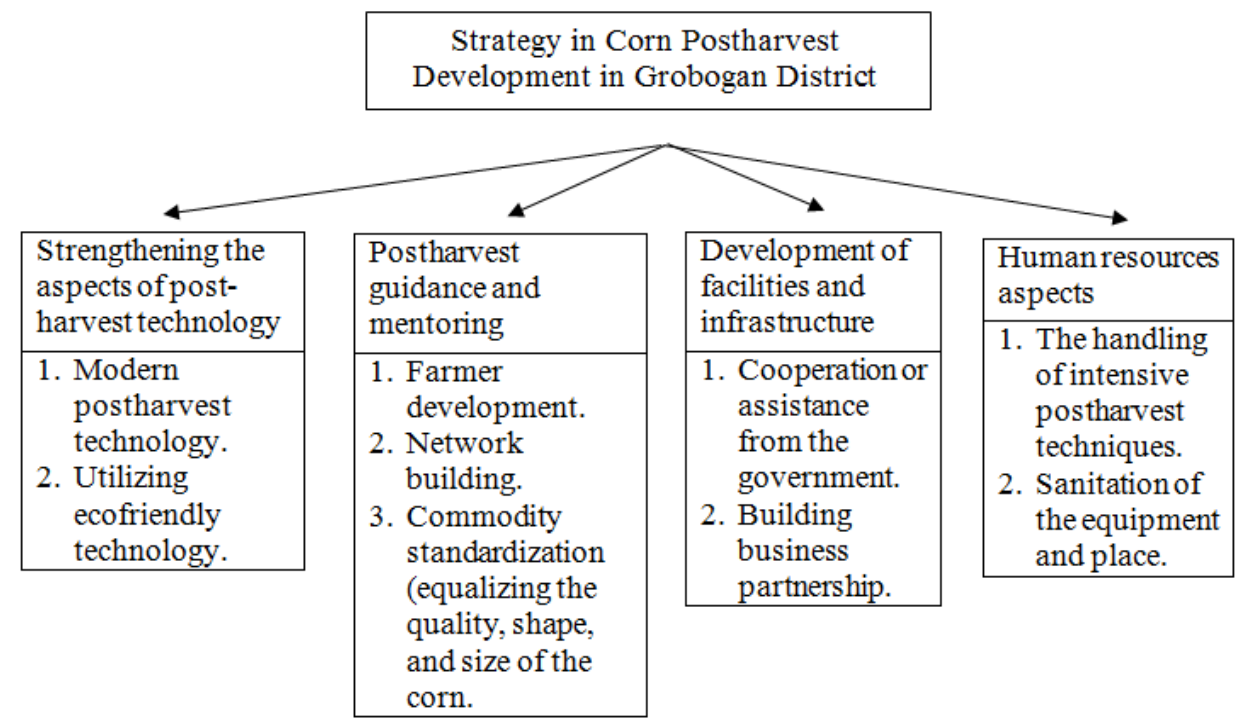

Figure 4 - Criteria and Alternatives of Priority Strategies

Corn postharvest development in Grobogan District has a very important role in enhancing the competitiveness of regional and national commodities. The goal is to increase the income of corn farming, to produce quality commodities and to improve the regional and national economies. The result of Hierarchy Process Analysis (AHP) shows that the criterion of corn postharvest guidance and assistance $(0.412)$ is the most important criterion in corn postharvest development strategy in Grobogan District. The next is the criteria for the reinforcement of aspects of postharvest technology (0.359), the criteria of development of facilities and infrastructure (0.139) and criteria of human resources aspects $(0.089)$.

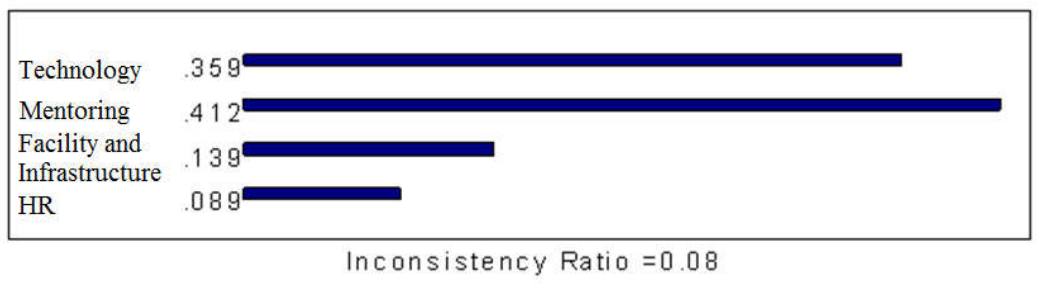

Figure 5 - Analysis Results of Development Strategy Criteria of Corn Postharvest Activities

The selection of postharvest guidance and mentoring criteria (Figure 5) as the main priority reflects that corn postharvest development farming in Grobogan District is very influential on mentoring issues. It is due to the fact that most corn farmers have not gained 
knowledge about the importance of producing corn with good quality. It is expected that with continuous guidance and assistance from relevant stakeholders, starting from harvesting process, postharvest process and selling the corn industries or markets, farmers can produce competitive commodities.

Aspects formulated in postharvest guidance and assistance of corn, among others: guidance to the corn farming groups, assistance in building the market networks and conducting supervision related to the standardization of corn commodities. From the three aspects (Figure 6), the most important one according to the key persons is the guidance to the corn farming groups (0.648). The selection of this aspect indicates that the main problem is the absence of knowledge, skills and awareness of farmers to be able to produce good commodities.

The next aspect chosen by the key persons is assistance in building a network to gain market access (0.232). Limited market access for the farmers makes the corn price below the price of the commodity. The price of corn in Febuary 2018 was IDR 3500/kg but there is still a lot of corn produced by farmers were purchased below that price.

The last aspect chosen by the key persons is to supervise the standardization of corn commodities (0.120). The key persons argue that the farmers do not yet know about the importance of good corn quality. Thus, it is necessary to supervise the standardization of corn quality.

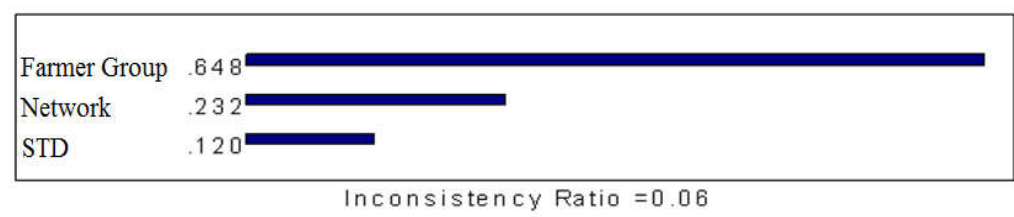

Figure 6 - Analysis Result of Alternative Strategy of Corn Postharvest Development Activity on Criteria of Postharvest Mentoring and Assistance

The second criterion in corn postharvest development in Grobogan District is the criteria of strengthening aspects of corn postharvest development. The technological aspect (Figure 7) consists of modern postharvest technology and the use of ecofriendly postharvest technology. Aspects of modern postharvest technology (0.762) become the main priority chosen for corn postharvest development. Most corn farmers are still using traditional technology so that technology improvement is needed to produce competitive corn that has good quality.

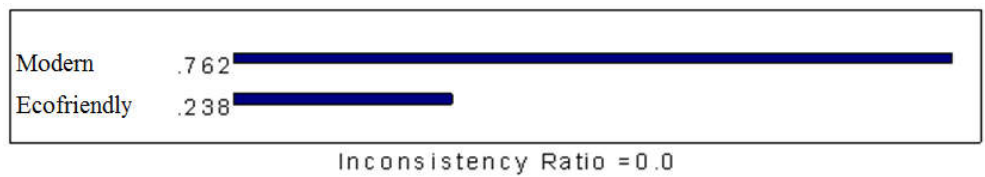

Figure 7 - Analysis Result of Alternative Strategies for Corn Postharvest Development Activities on Criteria for Strengthening Aspects of Postharvest Technology

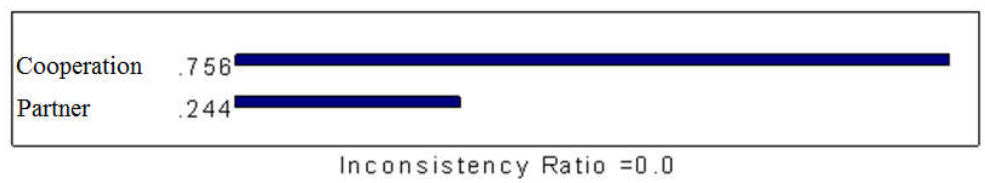

Figure 8 - Analysis Result of Alternative Strategies for Postharvest Development Activity on Criteria for Development of Facilities and Infrastructure

The aspect in achieving human resource improvement criteria (Figure 9) is an intensive postharvest handling technique and improved sanitation hygiene at postharvest facilities of corn farming. The chosen aspect by the key persons is the intensive handling of corn postharvest techniques. It is because postharvest activities have not been applied with Good 
Handling Practices (GHP), so it needs intensive handling so that the results can be maximized.

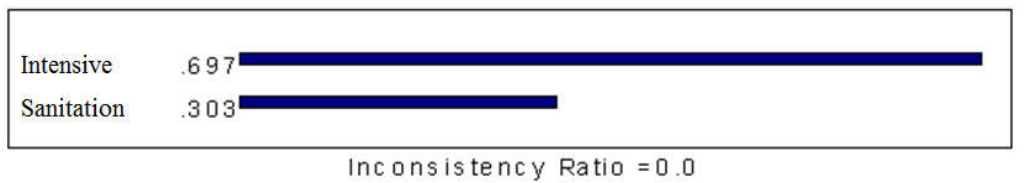

Figure 9 - Analysis Result of Alternative Strategies for Corn Postharvest Development Activities on Criteria of Human Resource Aspects

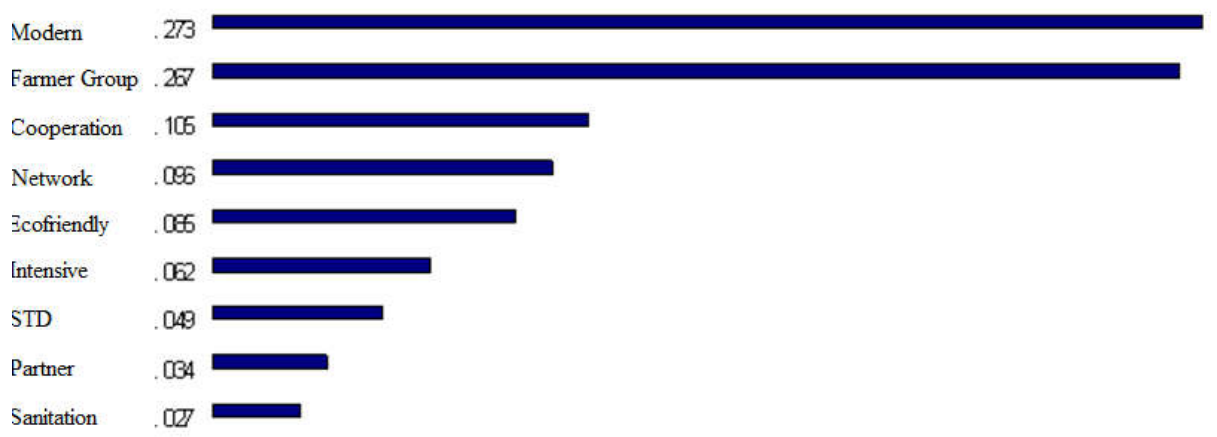

Figure 10 - Analysis Result of All Alternative Development Strategies for Corn Postharvest Activities

From the results of the overall analysis (Figure 10), based on the weight value in corn postharvest development strategy in Grobogan District using Analysis Hierarchy Process (AHP), the aspect of using modern postharvest technology is the most important aspect to achieve the expected goal. Meanwhile, the sanitation aspect is the least priority in achieving the expected goals.

\section{CONCLUSION}

Based on the results of postharvest development strategy of corn farming in Grobogan District, by applying an evaluation analysis of the application of Good Handling Practices (GHP) in corn postharvest activities at the farmer level, there were some obstacles including the drying process of corn that had not been appropriate, facilities and infrastructure of postharvest that had not been adequate and the absence of recording or bookkeeping activities undertaken by farmers in corn farming.

Based on the alternative strategy of SWOT analysis, it was obtained strategy on the first quadrant matrix which was S-O strategy that supported aggressive growth by exploiting the opportunity. The resulting strategies included: the improvement of postharvest technology, the application of commodity quality standards, the reinforcement of market development, sustainable consultation for the farmers, the development of postharvest supporting facilities, the improvement of commodity quality, and the improvement of commodity capacity and quantity.

The priority strategy of the Analysis Hierarchy Process (AHP), taking into consideration to the SWOT results, made the first priority criterion on guidance and mentoring of corn postharvest activities (0.412). The selection of postharvest guidance and mentoring criteria as the main priority reflected that postharvest development of corn farming in Grobogan District is very influential with mentoring issues. It was due to the fact that most corn farmers had no knowledge about the importance of producing corn with good quality and competitive. In the priority alternatives of the 9 aspects, the most important aspect in the priorities of corn postharvest development is the improvement of postharvest modern technology (0.273). With the improvement of technology, postharvest activities are expected to run effectively and efficiently so that corn commodities will be competitive. 


\section{REFERENCES}

1. Aji, A. A., Satria, A. and Hariono, B. (2014). 'Strategi Pengembangan Agribisnis Komoditas Padi Dalam Meningkatkan Ketahanan Pangan Kabupaten Jember', Jurnal Manajemen dan Agribisnis, 11(1), pp. 60-67.

2. BPS. (2016) Kabupaten Grobogan dalam Angka 2016.Provinsi Jawa Tengah.

3. Dinas Komunikasi dan Informatika. (2013). Kebutuhan Pakan Ternak. http://kominfo.jatimprov.go.id.Diakses pada tanggal 10 Agustus 2017.

4. Falatehan, A. F. (2008). 'Analisis Keunggulan Kompetitif dan Komparatif Pengusahaan Komoditi Jagung di Kabupaten Grobogan, Jurnal Agribisnis dan Ekonomi Pertanian, 2(1), pp. 1-15.

5. Firdaus, M. \& Farid M.A. (2008). Aplikasi Metode Kuantitatif Terpilih untuk Manajemen dan Bisnis. Bogor: IPB PRESS.

6. Fitriati, D., Hasbullah, R. and Rachmat, R. (2015). 'Penentuan Prioritas Sarana Pascapanen Jagung untuk Menurunkan Kehilangan Hasil Dengan Metode Analytical Hierarchy Process (AHP)', Jurnal Penelitian Pascapanen Pertanian, 12(2), pp. 10-19.

7. GPMT (Gabungan Perusahaan Makanan Ternak). (2015). Produktivitas Pakan Ternak. http://asosiasigpmt.blogspot.com. Diaksespada tanggal 12 Mei 2017.

8. Hermansyah, M., Soenoko, R. and Setyanto, N. W. (2013). 'Hazard Analysis and Critical Control Point (Haccp) Produksi Maltosa Dengan Pendekatan Good Manufacturing Practice (Gmp)', JEMIS, 1(1), pp. 14-20.

9. Kereth, G. A., Lyimo, M., Mbwana, H. A., Mongi, R. J., \& Ruhembe, C. C. (2013). Assessment of post-harvest handling practices: knowledge and losses of fruits in Bagamoyo district of Tanzania. J. Food Qual. Manag, 11.

10. Khalil (2016). 'Penanganan Pascapanen dan Kualitas Jagung sebagai Bahan Pakan di Kabupaten Pasaman Barat', Jurnal Peternakan Indonesia, 11(1), pp. 36-45.

11. Kusumaningrum, H. D. (2010). 'Contamination of Aspergillus flavus and Aflatoxin at Distribution Chain of Maize Based Food Product and its Influencing Factors', Jurnal Teknologi dan Industri Pangan, 11(2), pp. 171-176.

12. Leatemia, E. and Sari, M. (2012). 'Pelatihan Pembukuan Usahatani di Desa Hutumuri Kecamatan Leitimur Kota Ambon', Journal of Community Service, 1(1), pp. 17-25.

13. Lukman. (2013). From Farm to Table. Diakses pada tanggal 12 Desember 2017.

14. Maramba, U. (2018). 'The Influences Of Characteristic On Corn Farmers Revenue In East Sumba Regency (Case in Kiritina Village, Kambera Sub-District, East Sumba Regency)', Jurnal Ekonomi Pertanian dan Agribisnis (JEPA), 2(2), pp. 94-101.

15. Miskiyah (2010). 'Perubahan Sifat Fisik-Kimia Biji Jagung Pada Penyimpanan Dengan Perlakuan Karbondioksida (CO 2)', Jurnal Standarisasi Indonesia, 30(1), pp. 1-10.

16. Mohamad, M. (2016). 'Strategy of Corn Agribusiness Development in Ampana Tete Sub District of Tojo Una-Una Regency', Journal Agroland, 23(1), pp. 40-49.

17. Novitasari, D. R. (2016). 'Pengendalian Kualitas Statistika Produk Pakan Ternak Ayam Di PT. Japfa Comfeed Indonesia Tbk.', Jurnal Sains dan Seni ITS, 5(2), pp. 133-138.

18. Pamungkas, B. P. (2015). 'Pemetaan dan Strategi Pengembangan Agroindustri Olahan Kedelai di Kabupaten Grobogan', AGRISTA, 3(3), pp. 251-261.

19. Pennstate. (2012). Good Handling Practices (GHP) Food Safety Checklist Posh-Harvest Operations. College of Agricultural Sciences Cooperative Extension.

20. Pratama, B. R. (2014). 'Strategi Pengembangan Usahatani Kedelai Untuk Mewujudkan Ketahanan Pangan Indonesia', Journal of Economics and Policy, 7(2), pp. 103-213.

21. Rangkuti, F. (2006). Analisis SWOT Teknik Membedah Kasus Bisnis. Jakarta.

22. Revina, L. (2008). 'Analisis Faktor-Faktor Yang Mempengaruhi Produksi Dan Impor Jagung Di Indonesia', JEJAK Journal of Economics and Policy, 7(1), pp. 102-112.

23. Setiawan, K., Hartono, S. and Suryantini, A. (2014). 'Competitiveness Analysis of Coconut Commodities in Kupang District', Agritech, 34(1), pp. 88-93.

24. Sugiyono. (2001). Metode Penelitian Bisnis. Alfabeta. Bandung.

25. Yusrini, H. (2010). 'Teknik Pengujian Kadar Aflatoxin B1 pada Jagung Menggunakan Kit Elisa', Buletin Teknik Pertanian, 15(1), pp. 28-32. 